\title{
OPINTOVAPAATA VAI OPISKELUA TYÖAIKANA?
}

\section{Pohjoismaiden aikuiskoulutuksen tulevia kehitysstrategioita}

\author{
Pohjoismailla on vankka kokemus aikuiskoulutuksen \\ uudistusstrategioista aina kansansivistyksen perinteisestå \\ ideasta nykyaikaiseen, uusimman tekniikan turvin \\ toteutettuun työmarkkinakoulutukseen. Aikuiskoulutuksen \\ malli työelämåsså on ollut jaksottaisen koulutuksen malli. \\ Yhtenä sen keskeisenå takaajana on opintovapaa.
}

\begin{abstract}
Vaihtoehtoinen strategia on lisåtå työssä annettavaa koulutusta. Kirjoittaja esittelee artikkelissaan tåtå, ennen muuta Japanissa sovellettavaa käytåntöå ja vertaa sitä Ruotsiin. Hån näkee vuosisadan vaihteen eräånlaisena kåånnekohtana: selvä suuntaus on henkilöstökoulutuksen voimakas kasvu sekå huomion kiinnittäminen aikuisten lukutaidottomuuteen.
\end{abstract}

\section{Aikuiskasvatuksen pohjoismaisen yhteis- työn vahvistaminen}

Vuosittainen pohjoismainen aikuiskasvatuksen tutkimuskonferenssi on tervetullut uusi pohjoismainen yhteistyöhanke. On monia syitä vahvistaa pohjoismaista yhteistyötä aikuiskasvatuksessa. Meillä on samantapaiset kansansivistyksen traditiot ja työmuodot; sellaisia ovat erityisesti opintokerhot ja kansanopistot.

Myös Pohjoismaiden kokemukset hyvinvoinnin luomisesta sekä koulun ja aikuiskas. vatuksen osuudesta siinä ovat samanlaiset. Mahdollisuudet yhteistyöhön tutkimuksessa, dokumentoinnissa ja kokemustenvaihdossa ovat niin ikään hyvät.

Ilman pohjoismaista yhteistyötä aikuiskas. vatuksemme saattaakin jäädä Euroopan myl. lerryksissä unohduksiin. Hukumme Itä-Euroo- pan suurten muutosten kohuun tai jäämme Euroopan sitkeiden yhdentymisneuvottelujen varjoon.

Ehkä juuri näiden mullistusten takia on syy. tä selventää pohjoismaista aikuiskasvatuksen näkökulmaa. Pohjoismaat osoittautuvat erityisen kiinnostaviksi juuri siksi, että niillä on kokemuksia aikuiskasvatuksen uudistamisen strategioista, aina kansansivistyksen arvoperinteestä nykyaikaiseen, uusimman tekniikan turvin toteutettuun työelämän koulutukseen.

Askel pohjoismaisesta Kungälv-tutkijakokouksesta (kesäkuussa 1990) Euroopan suuriin kysymyksiin on oikeastaan lyhyempi kuin aavistammekaan. Välittömästi tutkijakokouksen jälkeen oli Tukholman lähistöllä konferenssi, jossa EY- ja EFTA-maiden edustajat käsittelivät teemaa New Challenges in Educa. tion and Training of the European Workforce. Konferenssin koollekutsujina olivat Ruotsin opetusministeriö ja kouluylihallitus. Sen mate- 
riaalina oli CERI/OECD:n teettämä selvitys teemasta The Expanding Learning Enterprise in Sweden sekä muutamia EY. ja EFTA-maiden aikuiskoulutuspolitiikkaa koskevia selvityksiä. Käsittelen tässä eräitä kysymyksiä, joita konferenssissa oli esillä. Jatkan samalla myös Ruotsissa käytävään aikuiskasvatuksen tulevaisuuden strategioita koskevaa keskustelua.

Tässä yhteydessä ei ole mahdollista ottaa esille kaikkea sitä, mitä eri Pohjoismaissa tapahtuu. Tanskassa ns. 10 kohdan ohjelma on aiheuttanut joitakin uudistuksia. Aikuiskasva. tuksen kehittämiskeskus on lisäksi aloittanut laajan ja tiiviin tutkimustoiminnan.

Norjassa kehitys on ollut jossain määrin py. sähdyksissä sen jälkeen, kun 80-luvun puolivälissä valmistui mietintö elinikäisestä oppimisesta. Suurkäräjillä ei ole tehty mitään ratkaisevia päätöksiä esimerkiksi opintojen rahoituksesta tai opintovapaasta. Tietyiltä osin voidaan sanoa, että aikuiskoulutuskysymyksiä on siirretty korkeammalle käsittelytasolle ja niitä on käsitelty Hernen selvityksen Mer kunskap til fler hengessä. Mainittu selvitys koskee korkeampaa koulutusta. Toinen kiinnostava asia on Trondheimin aikuispedagogisen instituutin (Norsk voksenpedagogisk institutt) kehitysstrategia, joka korostaa henkilöstökoulutusta ja henkilöstön kehittämistä.

Suomessa on 1980-luvun loppupuolella tehty useita tärkeitä aloitteita. Muun muassa on ilmestynyt mietintö Koulutus vuonna 2000. On saatu aikaan uudistus opintojen rahoituksesta ja ammatillisesta koulutuksesta. Suomessakin huomio kohdistuu työvoiman laatuun ja ammattitaitoon.

\section{Pätevyyskoulutus Ruotsissa ensi vuosisadan alussa}

Euroopan ja muun maailman poliittinen, taloudellinen ja kulttuurinen kehitys on vain yksi monista tekijöistä, joita on otettava huomioon suunniteltaessa tulevaisuuden koulutusta. Kuten monissa muissakin länsimaissa, myös Ruotsissa on edessä "ikäshokki": vanhojen ih. misten määrä kasvaa ja nuorista koulutetuista ihmisistä on puute.

Koska "tuoreen älymystön tuotanto" - inhimillisen pääoman teorian käyttääksemme abstraktia kieltä - on vain pari kolme prosenttia vuodessa, täytyy yhä enemmän turvautua keski-ikäiseen, jopa vanhempaan työvoimaan. Tämä koskee sekä naisia että miehiä, sekä ruotsalaisia että siirtolaisia.
Toinen syy panostaa aikuiskasvatukseen aiempaa enemmän on sukupolvien välinen koulutuksen ja tiedon kuilu, joka on syntynyt sen perusteella, milloin ja missä itse kukin on suorittanut oppivelvollisuutensa. Vuosisadan alussa syntyneet ihmiset ovat käyneet koulua kuusi, seitsemän vuotta, 1940-lukulaiset yhdeksän, kymmenen ja nykynuoret 12-13 vuotta.

Kuinka pitkä on koulutukseen käytettävä aika tulevaisuudessa? Käyvätkö ensi vuosisa. dan alussa syntyvät lapset koulua 15, 16 vai 17 vuotta? Miten integroidaan esikoulu ja koulu? Millainen on sellaisten siirtolaisryhmien tilanne, joilla ensimmäisen sukupolven ihmisillä on takanaan kotimaansa koulu ja toisella tai kolmannella sukupolvella Ruotsin nuorisokoulu?

Kouluylihallitus on selvittänyt aikuisväestön koulutustason muutoksia parissa viime vuosina ilmestyneessä kirjassa: Den nua utbildningsklyftan - 90-talets utmaning (Uusi koulutuksen kuilu - 90-luvun haaste) ja Det stora kunskapslyftet - Svensk vuxenutbildning inför år 2010 (Suuri tietotason nousu Ruotsin aikuiskoulutus vuoteen 2010 tulles. sa).

En puutu näiden kirjojen yksityiskohtiin, mutta ne osoittavat aikuisväestön koulutustason dramaattisen nousun 50 vuoden kulues. sa. Vuonna 1960 vielä 65 prosentilla työvoimasta oli takanaan lyhyempi kuin yhdeksän. vuotinen koulu. Vuonna 1986 prosenttiluku oli laskenut 23:een ja vuonna 2010 sen arvioidaan olevan neljä prosenttia.

\section{Aikuisten kouluopintojen kohtalo?}

Edellä olevia lukuja voi tulkita eri tavoin. Yhden tulkinnan mukaan aikuisten kouluopinnot menettävät merkityksensä vuoden 2010 jäl. keen, koska siihen mennessä kaikki ovat käyneet 12-vuotisen koulun. Tämä ajatus on viime vuosien aikana ollut jälleen ajankohtainen, koska myös aikuiskasvatuksesta on tullut ase julkisen sektorin varainkäytöstä käytävään keskusteluun.

Valtiokonttori, jota voidaan pitää valtion rationalisointielimenä, on ottanut puheeksi julkisen sektorin tuottavuuden parantamisen. Yhtenä ensisijaisena säästökohteena se pitää juuri kunnallista aikuiskoulutusta. Kantaansa se perustelee $\mathrm{mm}$. näillä koulutustason ko. hoamista koskevilla huomioilla. 
"Valtiokonttori voisi selvittää mahdollisuuk. sia kunnallisen aikuiskoulutuksen lopettamiseen tai vähentämiseen vuoteen 2000 men. nessä."

Tällaisia säästövaatimuksia on kuitenkin tarkasteltava sen tosiasian valossa, että tietä. misen ja osaamisen laatuvaatimukset kasva. vat ja muuttuvat yhteiskunnan muuttuessa. Ei voida ajatella, että yhdeksänvuotinen peruskoulu riittäisi tulevaisuuden tietoyhteiskunnassa.

Tulevaisuuden työelämä asettaa myös yhä suuremmat pätevyysvaatimukset. Ne johtuvat tuotantosysteemien muutoksista ja tietokoneiden käytön lisääntymisestä. Tämä kehitys mainitaan $\mathrm{mm}$. amerikkalaisessa tulevaisuu. dentutkimuksessa Workforce 2000. Work and workers for the 21st century, joka pari vuotta sitten tehtiin Hudson-instituutissa. Monet työtehtävät, joihin aikaisemmin riitti oppikoulu, vaativat nykyään korkeakoulutasoista koulutusta.

Kehitystä voi tulkita monin tavoin. Yksi selitys on, että todelliset pätevyysvaatimukset monilla aloilla ovat nousseet. Toisen mukaan työnantajat ovat nostaneet vaatimuksia koulutustason kohotessa. Luultavasti molemmissa on perää. Työnhakijalle syy on samantekevä; tosiasia on, että perusopinto- ja ammattitaitovaatimukset lisääntyvät. On myös tärkeätä huolehtia siirtolaisten oikeudesta peruskoulu. tukseen niin, etteivät he jäisi syrjään tietoyhteiskunnan vaatimusten kasvaessa.

\section{4. "Ruotsalainen malli", jaksottaisen koulutuksen malli}

Mainitsen tässä muutamia asioita Ruotsissa tehdystä tutkimuksesta The Expanding Learning Enterprise in Sweden. Education and training of the Swedish Labour Force. Ruotsin aikuiskasvatus on kautta vuosien ollut kansainvälisen ihailun kohteena. Mutta suuri suosio voi olla myös haitallista. Itsetyytyväisinä jäämme ehkä lepäämään laakereillamme. Kenties se malli, jonka kehitimme 70-luvulla, ei enää sovikaan yhteiskunnan vaatimuksiin vuoden 2000 jälkeen.

Ruotsin aikuiskasvatuksen piirteiden luetteleminen tässä saattaa vaikuttaa omahyväiseltä. Mutta silläkin uhalla, että minua syytetään pedagogisesta naiviudesta, otan niitä esille.

- Laki suo kaikille kansalaisille oikeuden opintovapaaseen.

- Mahdollisuudet saada opintotukea, joka kattaa kaikki kustannukset, vaihtelevat aikuiskasvatuksen eri alueilla; yhä vielä on myös suuria puutteita.
- Ruotsin aikuiskasvatuksen perustana on kolmentyyppistä järjestäjien yhteistyötä: kansansivistysorganisaatioiden (opintokerhot ja kansanopistot), kelpoisuuskoulutuksen järjestäjien (aikuisten peruskoulutus, grundvux, ja kunnallinen aikuiskoulutus, komvux) sekä ammatillisen koulutuksen (työmarkkinakoulutus, amu, ja henkilöstökoulutus).

- Koulutusta on tarjolla koko maassa, ja yh. teiskunta pyrkii tasa-arvoon ja alueelliseen ta. sapuolisuuteen.

- Aikuiskasvatus on tärkeä osa yleistä hyvin. vointipolitiikkaa ja välttämätön tuki työllisyys. politiikalle. Erityistä huomiota kiinnitetään siirtolaisten, vammaisten ja muiden koulutuksellisesti huono-osaisten ryhmiin.

- Ruotsin aikuiskasvatus on kansainvälisin mitoin mitattuna huomattavan laaja-alaista. Yli puolet aikuisista osallistuu vuosittain jonkinmuotoiseen järjestettyyn opetukseen. Tavallisimpia ovat opintokerhot ja nykyään yhä lisääntyvä henkilöstökoulutus, johon kumpaankin osallistuu noin 25 prosenttia aikuisväestöstä. Kunnalliseen aikuiskoulutukseen ja kansanopistojen opetukseen osallistuu noin 4.5 prosenttia aikuisista sekä työmarkkina. koulutukseen pari kolme prosenttia. Lisäksi ovat kansanopistojen erilliset kurssit, aikuisten peruskoulutus, siirtolaisten koulutus (sfi) ja muut erityismuodot.

\section{Jatkuva oppiminen työssä vai jaksottainen koulutus?}

Viime vuosikymmenien uudistuksena oppivelvollisuuden jälkeisessä koulutuksessa on ollut jaksottaisen koulutuksen periaate. Se merkitsee perinpohjaista muutosta yhteiskunnan tarjoamaan koulutukseen: se mahdollistaa koulutuksen, työn ja muiden tehtävien vuorottelun.

Paras tae tämän toteutumiselle on lakisääteinen oikeus opintovapaaseen, mahdollisuus opintotuen saamiseen sekä kurssien ja muiden opintomahdollisuuksien suuri tarjonta. On vain löydettävä sellaiset ajat, jolloin perheen ja muiden tehtävien ohessa pääsee opiskelemaan tehokkaasti.

Se voi kuitenkin olla hankalaa, koska nykyih. misen aika on tiukasti ohjelmoitu. Vaihtoehtoinen strategia onkin se, että järjestetään enemmän aikaa oppimiselle itse työssä, kotona tai muuna vapaa-aikana. Ideoita on saatavissa Japanista, ja Japani onkin ollut monille työpaikkakoulutusta suunnitteleville kiintoisa opintomatkan kohde.

Japanin esimerkin seuraaminen ei kuitenkaan ole aivan yksinkertaista, koska sielläkin on monia, joskus vastakkaisiakin tendenssejä. 
Ilmeisesti siellä on kuitenkin päästy varsin pitkälle työvoiman koulutustason ja työntekijöiden ammattitaidon kehittämisessä. Tämä koskee varsinkin miesten koulutusta. Tasa-arvokysymyksissä on paljonkin toivomisen varaa.

Japanilaisen mallin kiintoisa ja tärkeä piirre on elinikäisen työsuhteen, Life-Time-Employment, idea. Suurissa yrityksissä työnantaja takaa työntekijöilleen lähes elinikäisen työpaikan lisäksi myös jatkuvan työpaikalla annettavan täydennyskoulutuksen. Japanilaisten mielestä meidän jaksottaisen koulutuksen ja opintovapaan mallimme on vanhentunut. Työtehtävien ja työyhteisön kehittäminen nähdään siellä jatkuvana ongelmanratkaisuna ja oppimisena.

Kun pohdimme, miten lisätä mahdollisuuksia palkalliseen opintovapaaseen ja ammatilliseen täydennyskoulutukseen tai yleiseen aikuiskoulutukseen, japanilaisia kiinnostaa, miten suuri osa työajasta voidaan käyttää uuden oppimiseen. Eräät Ruotsissa tehdyt arviot osoittavat, että kaksi, kolme prosenttia työajasta käytetään henkilöstökoulutukseen. Japanissa tehtyjen arvioiden mukaan työssä oppimiseen ja ongelmanratkaisuun voidaan käyttää $10-20$ prosenttia työajasta.

"The most vital features of human re. sources development in contemporary Japan are as follows: First the workers" skills on the shop floor are characterised by intellectual skills, which are crucial in promotion efficiency. These skills in handling problems and changes vitally effect efficiency. To deal with problems and changes skillfully, knowledge of the mechanisms and structure of the machinery as well as the production process is essential, and this exactly comprises the content of intellectual skills. The Japanese feature is not that only Japanese wor. kers have these skills, but that the holders of these skills are diffused mode widely - even including production workers in large corporations - than in the West.

Second, this type of skills will become increasingly important. Intellectual skills are the most appropriate for dealing with problems where a high degree of computerisation prevails. Computerisation tends to put more unusual operations in hand. ling problems and changes in the hands of white-collar workers, so that the role of intellectual skills become more essential."

Koike (1989), sid. 27
Ajattelemisen aihetta japanilaisten koulutusmallissa antaa se, että kulttuurityöntekijöihin ei kiinnitetä suurta huomiota. Yksinkertaisesti on kysymys vain työn organisoinnista; voitaisiin puhua oppivasta organisaatiosta. Työssä oppiminen, on the job training, kuuluu tähän malliin luonnollisena osana ja sitä toteutetaan pitkäjänteisesti. Asiaan kuuluu myös kokemattomien työntekijöiden ohjaus ja opastus sekä osallistuminen työn ulkopuolisiin jatkokoulutuskursseihin, off the job training.

Epäilemättä Japanin menetelmä on ollut menestyksellinen, koska siellä - toisin kuin Ruotsissa - on onnistuttu jatkuvasti nostamaan tuottavuutta. Suurempi ongelma onkin ehkä, mitä tehdä voitolla. Maailman suurimmista pankeista kahdeksan sijaitsee Tokiossa.

\section{Työpaikka uutena aikuiskouluna - kysymys oppisopimuksesta?}

Myös USA:n työpaikkakoulutuksen kehitystä kannattaa tarkastella. Äskettäin ilmestyneessä raportissa The Learning Enterprise, jonka on julkaissut American Society for Training and Development, esitellään työpaikoilla annettavaa koulutusta. Amerikkalaiset työnantajat sijoittavat joka vuosi noin 30 miljardia dollaria, noin 200 miljardia Ruotsin kruunua, työpaikkakoulutukseen.

Lisäksi henkilöstökoulutus ja vapaamuotoinen työssä oppiminen maksaa 90-180 miljardia dollaria, yli tuhat miljardia Ruotsin kruunua. Valtava summa, johon verrattuna Ankkalinnassa rahoissaan kylpevä Roope Ankka on pelkkä piensäästäjä.

Verrattaessa Ruotsia Yhdysvaltioihin on kuitenkin muistettava, että Ruotsin väkiluku on vähemmän kuin viisi prosenttia USA:n väkiluvusta. Ruotsissa tehdyt laskelmat osoittavat, että julkisen ja yksityisen sektorin työnantajat sijoittavat 18.25 miljardia kruunua henkilöstö. koulutukseen. Jos kerromme 20 miljardia 25:llä, toteamme, että Ruotsi kestää kansainvälisen vertailun hyvin.

Todennäköisesti koulutuspalvelut USA:ssa myös jakaantuvat sosiaalisesti ja maantieteelli. sesti epätasaisemmin kuin Ruotsissa. Joidenkin suurien, johtavien yritysten henkilöstökoulutus on erittäin korkeatasoista. Yksityiset teollisuuslaitokset omistavat nykyään yli 20 yliopistoa. Mainittakoon, että McDonalds-yhtiöllä on oma yliopisto, the Hamburger University. 
Toinen aikuisopiskeluun liittyvä kysymys on opintososiaaliset ongelmat. Nykyään USA:ssa on varsin yleistä, että työnantaja antaa koulutusta palkallisena työaikana tai vastaa joistakin kurssikustannuksista sillä ehdolla, että työnte. kijä lupaa pysyä yrityksen palveluksessa tietyn ajan. Tämä tekee oppisopimuksen uudella tavalla tarpeelliseksi, mikä totisesti on sekä hyvä että huono asia. Yksi syy, miksi Ruotsissa 70-luvulla erotettiin opintovapaa opintojen rahoituksesta, oli tarve taata ihmiselle vapaus valita opiskelumuotonsa ja koulutuksensa sisältö.

\section{Vuosisadanvaihde käännekohtana aikuiskasvatuksen kehitys- strategioita etsimåssä}

Mitä aikuiskasvatuksen kansainvälistä kehitystä koskevia päätelmiä on tehtävissä edellä esitetyn perusteella? Selvä suuntaus on henkilöstökoulutuksen voimakas kasvu. Sen osoittaa myös OECD:n teettämä tutkimus The Expanding Learning Enterprise in Sweden, Education and training of the Swedish Labour Force. Toinen painopiste on huomion kiinnittäminen aikuisten lukutaidottomuuteen ja erityisesti lukutaidonopetukseen työpaikoilla.

Kolmas kehityssuunta, jota en ole tässä ko. vin paljon käsitellyt, liittyy kansansivistyksen asemaan. Aikoina, jolloin valtiontalous kiristyy, on vaara, että ruvetaan pälyilemään aikuiskasvatuksen rahoituksen vaihtoehtoja. Tehtäväkoulutuksen, uudistusrahastojen ja AMU:n (työmarkkinakoulutuksen) uudelleenorganisointi 80-luvun puolivälissä merkitsivät hyötyajattelun vahvistumista Ruotsin aikuiskasvatuksessa. Samalla vaarantui kansanliikkeiden ja kansansivistyksen asema, koska ne eivät ole perinteisellä tavalla tavoittaneet maksukykyisiä väestöryhmiä.

Muita tulevaisuuden koulutusstrategian aineksia ovat uuden tekniikan käyttö etäope. tuksessa, korkeakouluopintoihin pääsyn laajentaminen sekä yhä useammilla tahoilla lisääntynyt kiinnostus dokumentoida ja mitata aikuiskasvatusta sekä yksilöitä että yhteiskun. taa varten.

On selvää, että nämä uudet näkymät koettelevat Ruotsin aikuiskoulutuksen kykyä tulevaisuuden haasteiden kohtaamiseen. Eri tahoilla keskustellaan siitä, millaista aikuiskoulutusta meidän on vuosisadanvaihteeseen mennessä kehitettävä. Mainitsen tässä vain muutamia aloitteita, jotka ovat olleet vireillä 80 - ja 90-lukujen taitteessa: o Kansanopiston tulevaisuutta on selvitelty kansanopistotoimikunnassa, jonka tuloksena on valmistunut kaksi mietintöä.

o Opintokeskusten taloudesta ja tulevaisuudesta on käyty keskustelua Ruotsin vapaan sivistystyön yhteisjärjestön (Folkbildningsförbundet) ja opetusministeriön yhteistyöryhmässä, jonka työskentelyn pohjana on kouluylihallituksen raportti.

o Kouluylihallitus on saanut hallitukselta tehtäväkseen tarkastaa komvuxin ja grundvuxin resurssit ja tulokset, ja valtiokonttori on tehnyt hyvin kriittisen grundvuxin tarkastuksen.

o Teollisuusministeriö on asettanut tuottavuusvaliokunnan.

o Useita vuosia sitten ehdotettu pätevyyskomitea (kompetenskommittén) on nyt asetettu. Sen tehtävänä on kartoittaa henkilöstökoulutuksen määrä ja suunta.

- Sekä LO (Landsorganisationen, Ruotsin "SAK") että TCO (Tjänstemännens Centralorganisation, Virkamiesten keskusliitto) ovat ehdottaneet opintotuen korottamista ja työntekijöiden oikeutta toisaalta kaksiviikkoiseen henkilöstökoulutukseen, toisaalta lukion ammattilinjan tasoa vastaavaan perusaineiden eli ruotsin, englannin ja matematiikan opiskeluun.

o Kouluylihallitus on viimeisimmässä määrärahaesityksessään ehdottanut aikuiskasvatuksen viisivuotisen kehittämisohjelman laatimis. ta.

o Hallituksen esitys siirtolaisten ruotsin kielen opetuksesta on annettu eduskunnalle vuoden 1990 alussa.

o On asetettu uusi toimikunta selvittämään opintososiaalisia kysymyksiä, erityisesti aikuisopiskelun kannalta.

o On perustettu yhteistyöelin pohtimaan lukion, komvuxin, AMU:n ja korkeakoulujen resurssien tehokkaampaa, sekä paikallista että alueellista hyödyntämistä.

Tässä muutamia tulevaisuuden aikuiskoulutuspolitiikan rakennuskiviä. Göran Persson, aikuiskoulutuksesta vastaava ministeri, on vuoden 1991 alussa tehnyt kaksi aikuiskasvatusta koskevaa esitystä, toinen koskee vapaata sivistystyötä ja sen ehtoja, toinen tutkintoihin tähtäävää opiskelua (lukio ja komvux).

Opetusministeriö on työskennellyt myös innokkaasti ns. kouluprojekti parissa. Kysymys on siitä, miten koulupolitiikkaa voidaan harjoittaa hajautetussa ja tavoitetietoisessa koulu. 
laitoksessa. On selvitettävä koulutussektorin valtionavun perusteet, keskushallinnon rooli menettelytapakysymyksissä, opetuksen suunnittelussa, arvioinnissa ja seurannassa. Lisäksi on tekeillä lukion, varsinkin sen ammattilinjojen laajennus- ja uudistusprojekti.

Osana näitä muutoksia 1.7.1991 lakkautettava kouluylihallitus korvataan voimakkaasti supistetulla kouluhallinnolla. Vapaan sivistys. työn tuki siirretään suoraan opintokeskuksia ja kansanopistoja edustavan elimen jaettavak. si. Nämä osapuolet muodostaisivat uuden, hyvin itsenäisen vapaan sivistystyön neuvoston.

Kun suunnitellaan tulevaisuuden aikuiskoulutusta Ruotsissa ja muualla Pohjoismaissa, on tärkeimpiä strategiakysymyksiä se, miten voidaan taata ihmisen oikeus vapaaseen tiedonhankintaan samalla, kun kaupallisuus ja hyötytavoitteisuus yhä lisääntyvät. Millainen oikeus yksilöllä tulee olla tiedonhankintaan ja oppimiseen varsinaisen oppivelvollisuuden jälkeen? Juuri tästä näkökulmasta on mielen. kiintoista, että uusi koululaki korostaa kuntien vastuuta sekä kartoittaa vähän koulutusta saanut väestö (koulua vähemmän kuin yhdeksän vuotta) että tarjota heille mahdollisuus täyden. tää vastaava, koulun 9. vuosikurssi. Aiemmin tällainen oikeus oli 6 . vuosikurssin suhteen.
Onko yhteiskunnan taattava kaikille kansa. laisille jokin perustaso kansalaispätevyydessä? Jos on, miten sitten tämä oikeus on toteutettava? Onko se taattava lailla vai sopimuksella? Miten voidaan ihmisen oikeus elpymiseen tai kuntoutumiseen liittää yleisen ajankäyttöpolitiikan osaksi niin, että opintovapaa sisältyy siihen samalla tavalla kuin vanhempainloma, sairausloma tai jokin muu loma?

Entä kuka saa hallita ajankäyttöpankkia? Voiko sieltä ottaa varoja niin kuin pankkiauto. maatista amerikkalaisen Michigan Opportunity Card -mallin mukaan. Silloin yksilön koke. musprofiilia verrataan tarjolla oleviin koulutusmahdollisuuksiin? Vai onko aika kypsä siihen, että hylkäämme perinteisen opintovapaapolitiikan ja sen sijaan yritämme lisätä oppimisaikaa työssä? Mitä silloin tapahtuu heikosti koulutetuille ja osattomille ryhmille, joihin kuuluu myös siirtolaisia ja vammaisia aikuisia? Ovatko hekin tervetulleita oppivan yhteiskunnan täysivaltaisiksi jäseniksi?

Vai onko ajatus oppivasta organisaatiosta keino, jolla työnantajalle annetaan valta huo. lehtia yhteiskunnan koulutuksesta - siis myös yksilön oikeudesta omaan tiedonhan. kintaan ja oppimiseen? Näistä kysymyksistä meidän on keskusteltava, kun pohdimme vuosisadanvaihteen aikuiskoulutuksen suuntaa. Tässä keskustelussa pohjoismaalaisten yhteiset kokemukset ovat arvokkaita. 


\section{AIKUISKASVATUS}

\section{The Finnish Journal of Adult Education}

Vol. 11, 2/91

ISSN 0358-6197

Summary

Abrahamsson Kenneth 1991. Opintovapaata vai opiskelua työaikana? Pohjoismaiden aikuiskoulutuksen tulevia kehitysstrategioita.

- Tietämisen ja osaamisen laatuvaatimukset kasvavat ja muuttuvat yhteiskunnan muuttuessa. Tulevaisuuden tyőelämä asettaa yhå suuremmat påtevyysvaatimukset. Artikkelissa käsitellaaån rinnakkain ns. ruotsalaista mallia eli jaksottaisen koulutuksen mallia ja Japanin ehkä pisimmälle soveltamaa työssä opiskelun ja oppimisen mal. lia. Artikkelissa pohditaan nåiden kahden koulu. tusmallin soveltuvuutta pohjoismaiseen yhteis. kuntaan.

Aikuiskasvatus 11.2.
Abrahamsson Kenneth 1991. Study leave or study while at work? Future development strate. gies in Nordic adult education.

- The quality requirements connected to knowing and knowing how are growing and changing with changes in society. The working life of the future will impose increasingly higher qualification requirements. The author makes a comparison of the so-called Swedish model (i.e. period training) and the model of studying and learning at work. The latter model finds its probably most far.reaching applications in Japan. The applicability of these two training models to the Nordic society is examined.

Aikuiskasvatus 11,2. 